\title{
Predictive markers for hepatitis C virus infection among Brazilian inmates
}

\author{
Marcadores preditivos para infecção do vírus da hepatite C \\ em presidiários brasileiros
}

\author{
Harnoldo Colares Coelho ${ }^{1}$, Sabrina Alberti Nóbrega de Oliveira ${ }^{2}$, Juliana Custódio Miguel², \\ Maria de Lourdes Aguiar Oliveira ${ }^{2}$, José Fernando de Castro Figueiredo ${ }^{3}$, \\ Gleici Castro Perdoná ${ }^{3}$ and Afonso Dinis Costa Passos ${ }^{3}$
}

\begin{abstract}
Hepatitis C virus (HCV) infection has quite high prevalence in the prison system, reaching rates of up to $40 \%$. This survey aimed to estimate the prevalence of HCV infection and evaluate risk factors for this exposure among male inmates at the Ribeirão Preto Prison, State of São Paulo, Brazil, between May and August 2003. A total of 333 participants were interviewed using a standardized questionnaire and underwent immunoenzymatic assaying to investigate anti-HCV. The prevalence of HCV infection among the inmates was 8.7\% (95\% CI: 5.7-11.7). The participants' mean age was 30.1 years, and the prevalence was predominantly among individuals over 30 years of age. Multivariate analysis showed that the variables that were independently associated with HCV infection were age $>30$ years, tattooing, history of previous hepatitis, previous injection drug use and previous needle-sharing.
\end{abstract}

Key-words: Hepatitis C. Prisons. Prevalence. Risk factors.

\section{RESUMO}

Infecção pelo vírus da hepatite C no sistema prisional apresenta elevada prevalência, chegando a atingir cifras superiores a 40\%. Esta pesquisa objetivou estimar a prevalência do HCV e avaliar fatores de risco para esta exposição na população masculina carcerária da Penitenciária de Ribeirão Preto - SP, no período de maio a agosto de 2003. Um total de 333 participantes foi submetido à aplicação de um questionário padronizado e a ensaio imunoenzimático para pesquisa de anti-HCV. A prevalência encontrada de infecção pelo HCV nos presidiários foi de 8,7\% (IC 95\%: 5,7-11,7). A média de idade dos participantes foi de 30,1 anos, com a prevalência predominando nos indivíduos acima de 30 anos. Na análise multivariada, as variáveis que se mostraram associadas de forma independente à infecção pelo HCV foram idade > 30 anos, tatuagem, história prévia de hepatite, passado de uso de droga injetável e passado de compartilhamento de agulhas.

Palavras-chaves: Hepatite C. Prisões. Prevalência. Fatores de risco.

The inmate population is considered to be at high risk of infections such as human immunodeficiency virus (HIV), hepatitis $\mathrm{B}$, hepatitis $\mathrm{C}$ and sexually transmitted diseases (STDs), because of the imprisonment conditions. Moreover, factors such as marginalization, drug addiction, low socioeconomic level and the precarious condition of the healthcare system in Brazil contribute towards dissemination of these diseases in prisons ${ }^{17}$.

Investigations on the impact of hepatitis $\mathrm{C}$ within the prison system started before serological tests for hepatitis C virus (HCV)

\footnotetext{
1. Faculty of Pharmaceutical Sciences of Ribeirão Preto, University of São Paulo, Ribeirão Preto, SP, Brazil. 2. National Reference Laboratory for Viral Hepatitis, Oswaldo Cruz Institute, Oswaldo Cruz Foundation, Rio de Janeiro, Brazil. 3. Medical School of Ribeirão Preto, University of São Paulo, Ribeirão Preto, SP, Brazil.

Address to: Prof. Harnoldo Colares Coelho. Department of Clinical, Toxicological and Bromatological Analysis, Faculty of Pharmaceutical Sciences of Ribeirão Preto. Via do Café, S/N, 1404-903. Ribeirão Preto, SP, Brazil.

Tel: 55 16 3602-0660; Fax: $55163602-4725$.

e-mail: harnoldo@usp.br

Received in 26/11/2008

Accepted in 20/07/2009
}

diagnosis were available, in 1985 and 1987, when Brewer et al ${ }^{5}$ investigated HIV transmission among inmates. A few years later, Vlahov et $\mathrm{al}^{25}$ analyzed stored serum samples from these two studies, and found an HCV infection rate of $38.1 \%$, with an incidence of 1.1 per 100 individuals/year.

In the United States, the prevalence of $\mathrm{HCV}$ infection in prisons is estimated to be between $15 \%$ and $30 \%$, which indicates a rate as much as 20 times higher than the rate found among the general population ${ }^{4}$. High frequencies of viral infection have also been described in England (7\%) ${ }^{26}$, Norway $(46 \%)^{13}$ and Ghana $(19.2 \%)^{1}$. In Brazil, studies carried out at different times have revealed prevalences ranging from $6.3 \%$ to $41 \%^{712} 18$.

Taken together, these figures highlight the urgent need to implement prevention programs directed towards prison settings, in order to prevent or reduce the transmission of viral infection during incarceration. The aim of this study was to estimate the prevalence of HCV infection and to assess the main risk factors among a male inmate population at the Ribeirão Preto Prison, State of São Paulo, Brazil. 


\section{MATERIAL AND METHODS}

Study population. The prison in Ribeirão Preto has four closed and one semi-open confinement pavilions. In May 2003, nearly 1,030 prisoners were incarcerated. To estimate the sample size for this study, all 893 inmates under a closed confinement regime were used as the reference population. A minimum sample size of 322 subjects was calculated by assuming an HCV seroprevalence of $30 \%, 5 \%$ precision and a $95 \%$ confidence interval.

Data collection procedures. A simple random sampling procedure was used to select participants. One hundred inmates from each of the four closed-regime pavilions were selected at random. All the selected inmates who agreed to participate in this study signed a consent statement. The data and blood collections were carried out from May to August 2003. Each participant answered a questionnaire that sought demographic data and information on the length of time in prison and the following risk factors for HCV exposure: use of both intravenous and nonintravenous illegal drugs, tattoos, sexual orientation and blood transfusions. All the questionnaires were applied by the same investigator. This project was approved by the Research Ethics Committee of the Clinical Hospital of Ribeirão Preto School of Medicine, University of São Paulo.

Laboratory testing. Anti-HCV was detected in blood samples by means of a commercial immunoenzymatic assay (Bioelisa HCV, Biokit, Spain). Initially reactive samples were retested in duplicate and the final result consisted of concordant results from at least two replicates.

Statistical analysis. All data were entered into the Epi Info 6.04 software, and were subsequently transported to the STATA 9.0 statistical package. Chi-square and Fisher's exact tests were used to assess associations between demographic/epidemiological variables and HCV infection. Multiple logistic regressions were performed for variables presenting a $\mathrm{p}$ value less than or equal to 0.25 in the univariate analysis ${ }^{14}$.

\section{RESULTS}

Out of 345 inmates who answered the questionnaire and signed the consent statement, 12 refused to give a blood sample. Effectively, 333 individuals who allowed blood collected and answered the questionnaire took part in the study. The participants' ages ranged from 19 to 69 years, with mean and median of 30.1 years and 28 years, respectively. More than half of the subjects were born either in the city of Ribeirão Preto or in the neighboring region. Subjects born in other cities in the State of São Paulo or in other Brazilian states represented 24.6\% and $22.5 \%$ of the sample, respectively. The overall prevalence of HCV infection was $8.7 \%$ (95\% CI: 5.7-11.7).

Table 1 shows that the HCV prevalence was higher among individuals aged over 30 years. It ranged from $14.5 \%$ among those between 31 and 35 years of age to 20\% among those between 36 and 45 years of age (grouping the participants into two categories:
TABLE 1

Hepatitis $\mathrm{C}$ virus prevalence according to age, certain risk factors and previous history of hepatitis and jaundice. Ribeirão Preto Prison, São Paulo, Brazil, 2003.

\begin{tabular}{|c|c|c|c|c|}
\hline Variable & Number & $\mathrm{HCV}+$ & Percentage & $\mathrm{p}$ \\
\hline \multicolumn{5}{|l|}{ Age (years) } \\
\hline $19-24$ & 96 & 1 & 1.0 & \multirow[t]{5}{*}{$<0.001$} \\
\hline $25-30$ & 107 & 6 & 5.6 & \\
\hline $31-35$ & 55 & 8 & 14.5 & \\
\hline $36-45$ & 60 & 12 & 20.0 & \\
\hline$>45$ & 15 & 2 & 13.3 & \\
\hline \multicolumn{5}{|l|}{ Tattoo } \\
\hline yes & 120 & 23 & 19.2 & \multirow[t]{2}{*}{0.070} \\
\hline no & 213 & 6 & 2.8 & \\
\hline \multicolumn{5}{|l|}{ Sexual preference } \\
\hline heterosexual & 332 & 28 & 8.4 & \multirow[t]{2}{*}{0.080} \\
\hline homosexual & 1 & 1 & 100.0 & \\
\hline \multicolumn{5}{|l|}{ Previous STD } \\
\hline yes & 114 & 16 & 14.0 & \multirow[t]{2}{*}{0.020} \\
\hline no & 219 & 13 & 5.9 & \\
\hline \multicolumn{5}{|c|}{ Previous use of illegal non-injection drugs } \\
\hline yes & 271 & 29 & 10.7 & \multirow[t]{2}{*}{$<0.001$} \\
\hline no & 62 & - & - & \\
\hline \multicolumn{5}{|c|}{ Previous use of illegal injection drugs } \\
\hline yes, with needle sharing & 11 & 8 & 72.7 & \multirow[t]{3}{*}{$<0.001$} \\
\hline yes, without needle sharing & 18 & 5 & 27.8 & \\
\hline no & 304 & 16 & 5.3 & \\
\hline \multicolumn{5}{|l|}{ Sex with illegal drug user } \\
\hline yes & 152 & 18 & 11.8 & \multirow[t]{2}{*}{0.060} \\
\hline no & 181 & 11 & 6.1 & \\
\hline \multicolumn{5}{|l|}{ Previous hepatitis } \\
\hline yes & 27 & 8 & 29.6 & \multirow[t]{2}{*}{$<0.001$} \\
\hline no & 306 & 21 & 6.9 & \\
\hline \multicolumn{5}{|l|}{ Previous jaundice } \\
\hline yes & 24 & 6 & 25.0 & \multirow[t]{2}{*}{0.010} \\
\hline no & 309 & 23 & 7.4 & \\
\hline Total & 333 & 29 & 8.7 & \\
\hline
\end{tabular}

under 30 and over 30 years: $\mathrm{p}<0.001$ ). Concerning medical history, the inmates who reported previous hepatitis, jaundice and STDs also showed higher frequencies of HCV. Only one inmate reported having had sex with other men, thus making it difficult to assess the association between this variable and HCV. Marginal statistical associations were found among those who reported having had heterosexual intercourse with illegal drug users ( $\mathrm{p}=$ $0.06)$ and having undergone tattooing $(\mathrm{p}=0.07)$. On the other hand, previous non-intravenous illegal drug abuse was strongly associated with HCV $(\mathrm{p}<0.001)$.

HCV infection was significantly higher among injection drug users (IDUs), compared with individuals who did not inject drugs $(\mathrm{p}<0.001)$. Among IDUs, the positive rate was much higher among inmates who shared needles $(72.7 \%)$, compared with those who did not (27.8\%).

After multiple logistic regression analysis (Table 2), the variables identified as independent predictors for HCV infection 
TABLE 2

Final logistic regression model for variables associated with hepatitis $\mathrm{C}$ virus infection. Ribeirão Preto Prison, São Paulo, Brazil, 2003.

\begin{tabular}{lcrc}
\hline Variable & Odds ratio & $95 \% \mathrm{CI}$ & $\mathrm{p}$ \\
\hline Age $>$ 30 years & 7.3 & $2.4-21.3$ & 0.00 \\
Previous hepatitis & 3.8 & $1.1-12.9$ & 0.03 \\
Tattoo & 3.2 & $1.05-10.0$ & 0.04 \\
IDUs who did not share needles & 4.1 & $1.1-14.2$ & 0.03 \\
IDUs who shared needles & 48.8 & $9.3-254.5$ & 0.00 \\
\hline
\end{tabular}

95\% CI: 95\% confidential interval, IDUs: injection drug users

were: age above 30 years ( $\mathrm{OR}=7.3 ; 95 \% \mathrm{CI}: 2.4-21.3)$, previous history of hepatitis (OR $=3.8 ; 95 \% \mathrm{CI}$ : 1.1-12.9), having a tattoo $(\mathrm{OR}=3.2 ; 95 \% \mathrm{CI}: 1.05-10.0)$, previous injection drug use without needle-sharing (OR $=4.1 ; 95 \% \mathrm{CI}: 1.1-14.2)$ and previous injection drug use with needle-sharing $(\mathrm{OR}=9.3 ; 95 \%$ CI: 9.3-254.5).

\section{DISCUSSION}

Worldwide, the prevalence of hepatitis $\mathrm{C}$ reported in prisons is generally high, regardless of the regions in which studies were conducted, with 34.3\% and 32.1\% in the United States ${ }^{10} 16 ; 21.8 \%$ in Dublin, Ireland ${ }^{15} ; 10 \%$ in Durango, Mexico 33 30\% in Hamedan, Iran $^{2}$ and $16.6 \%$ in Quebec, Canada ${ }^{22}$.

In Brazil, the first reports on the impact of hepatitis $\mathrm{C}$ among incarcerated populations were produced from two different studies in 1993 and 1994, carried out in Carandiru prison ${ }^{18}$ and Casa de Detenção ${ }^{12}$ in São Paulo. Both reports described very high prevalences of HCV infection, with rates reaching 34\% and 41\%, respectively. However, more recent investigations conducted in Minas Gerais and São Paulo over the last few years, have reported lower prevalences than those of the first reports: $6.3 \%^{7}$ and $6.0 \%{ }^{6}$, respectively, i.e. much closer to our findings.

Older age has been associated with HCV infection in different settings. In Brazil, about half of the hepatitis $C$ cases notified (51.7\%) between 2001 and 2006 were within the age range from 40 to 59 years $^{23}$. This corroborates our results, in which a prevalence of $48.3 \%$ was found among subjects older than 36 years (14 cases). However, different results (i.e. higher risk among young individuals) were found by Guimarães et $\mathrm{a}^{12}$, who reported that age under 28 was a risk factor for HCV, and by Pallás et $\mathrm{al}^{21}$, who showed a higher proportion of infected subjects between 26 and 30 years of age $(32 \%)$.

Inmates present higher risk of STDs, compared with the general population, possibly because of their different behavioral patterns and general hygiene practices. In the present study, previous history of STDs was significantly associated with HCV infection in univariate analysis. However, this factor was not considered to be an independent predictor for viral infection, thus suggesting that there must be other factors that confound the relationship between these two variables. It is also important to take into account the small number of inmates who reported ulcerative STDs and the low efficiency of sexual transmission of HCV.
There have been reports of sexual contact among inmates, especially associated with injection drug use $\mathrm{e}^{11}$. However, such behavior was not observed in the present study. Apart from the stigma involved, which may have caused the prisoners to deny such practices, inmates who were transvestites or male sex professionals were preferentially incarcerated in the "safe" area, which houses those who need to be isolated from the other inmates for safety reasons. Since the inmates in the "safe" area were excluded from this study, we were unable to adequately analyze this issue.

Univariate and multivariate analysis did not demonstrate any association between HCV presence and sexual intercourse with illegal drug users. This finding was also observed by Adjei et $\mathrm{al}^{1}$, and one possible explanation for this could be the low efficiency of transmission of this virus through sexual intercourse.

In the present study, non-injection drug use and HCV infection were significantly associated in univariate analysis. There is a constant link between the inmate population and the use of such substances, since their use is considered to be a criminal offense in Brazil. Among intranasal users of illegal drugs, HCV presence may be associated with sharing the instrument used for drug intake? Drug abuse (especially cocaine) damages the nasal mucosa and bleeding episodes when using the same instrument may favor viral transmission. However, the causal pathway to infection still remains unclear.

Injection drug use is considered to be the greatest risk for HCV infection, worldwide ${ }^{22} 26$. In our study, inmates who reported previous use of intravenous illegal drugs showed significantly higher frequencies of infection, especially among those who reported needle-sharing. These results are in consonance with the literature, which shows that HCV infection occurs shortly after starting to use intravenous drugs, and even earlier than hepatitis $B$ virus (HBV) or HIV infections ${ }^{27}$. Furthermore, the literature shows that needle-sharing is a key risky behavioral pattern for HCV transmission among injection drug users ${ }^{20}$.

Inmates who presented tattoos were more likely to be infected than their non-tattooed counterparts were. It is important to emphasize that the risk of $\mathrm{HCV}$ infection through tattooing could be even higher when it is done inside the prison institution. In such settings, tattooing involves the use of tools and objects without even minimal hygiene conditions, thereby favoring infection by different pathogens, especially those that present high efficiency of parenteral transmission, like HCV ${ }^{24}$.

The results from this study and from other studies carried out over recent years ${ }^{67}$ indicate that the HCV prevalence among prisoners in Brazil seems to be declining, in comparison with fifteen years ago. The greater specificity of more recent laboratory tests may partially explain these differences. The possible reasons for the apparent reduction in HCV infection include the impact caused by campaigns against HIV in this particular prison, through the Ribeirão Preto Municipal Program for STD/AIDS ${ }^{8}$ and, most notably, the observed replacement of injectable cocaine (which was very popular some years ago) by the consumption of crack, which has become an important form of cocaine addiction more recently ${ }^{19}$. 
Nevertheless, the findings from this study show that hepatitis $\mathrm{C}$ is still an important health problem within the Brazilian prison system. They indicate that viral transmission can be associated with several factors and behavioral patterns, such as the socioeconomic origin of the inmates, and frequently with risky practices like tattooing, needle-sharing for injection drug use and multiple unprotected sexual intercourse, within an unfavorable institutional environment. This information is pivotal for tailoring prevention programs and guiding specific socioeducational measures that aim to reduce or prevent HCV transmission within the prison setting. However, data on viral hepatitis among inmates is still very scarce in Brazil, and this points out the need for continuous epidemiological studies aimed at monitoring infection and directing prevention.

\section{REFERENCES}

1. Adjei AA, Armah HB, Gbagbo F, Ampofo WK, Quaye IKE, Hesse IFA, Mensah G. Prevalence of human immunodeficiency virus, hepatitis $\mathrm{B}$ virus, hepatitis $\mathrm{C}$ virus and syphilis among prison inmates and officers at Nsawam and Accra, Ghana. Journal of Medical Microbiology 55: 593-597, 2006.

2. Alizadeh AH, Alavian SM, Jafari K, Yazdi N. Prevalence of hepatitis C virus infection and its related risk factors in drug abuser prisoners in Hamedan-Iran. World Journal of Gastroenterology 11: 4085-4089, 2005.

3. Alvarado-Esquivel C, Sablon E, Martinez-Garcia S, Estrada-Martinez S. Hepatitis virus and HIV infections in inmates of a state correctional facility in Mexico. Epidemiology and Infection 133: 679-685, 2005.

4. Boutwell AE, Allen SA, Rich JD. Opportunities to address the hepatitis C epidemic in the correctional setting. Clinical Infectious Diseases 40(suppl 5): S367-S371, 2005.

5. Brewer T, Vlahov D, Taylor E, Hall H, Munoz A, Polk B. Transmission of HIV-1 within a statewide prison system. AIDS 2: 363-367, 1988.

6. Carvalho HB, Seibel SD, Burattini MN, Massad E, Reingold A. Vulnerabilidade às infecções pelo HIV, hepatite $\mathrm{B}$ e $\mathrm{C}$ e sífilis entre adolescentes infratores institucionalizados na Cidade de São Paulo, Brasil. Jornal Brasileiro de Doenças Sexualmente Transmissíveis 15: 41-45, 2003.

7. Catalan-Soares B, Almeida R, Proietti A. Prevalence of HIV-1/2, HTLV-I/II, hepatitis $\mathrm{B}$ virus (HBV), hepatitis $\mathrm{C}$ virus (HCV), Treponema pallidum and Trypanosoma cruzi among prison inmates at Manhuaçu, Minas Gerais State, Brazil. Revista da Sociedade Brasileira de Medicina Tropical 33: 27-30, 2000.

8. Coelho HC. Prevalência e fatores de risco para a infecção do HIV na população carcerária masculina da Penitenciária de Ribeirão Preto. Dissertação de Mestrado, Universidade de São Paulo, Ribeirão Preto, SP, 2004.

9. Conry-Cantilena C, VanRaden M, Gibble J, Melpolder J, Shakil A0, Viladomiu L, Cheung L, DiBisceglie A, Hoofnagle J, Shih JW, Kaslow R, Ness P, Halter HJ. Routes of infection, viremia, and liver disease in blood donors found to have hepatitis $\mathrm{C}$ virus infection. Routes of infection, viremia, and liver disease in blood donors found to have hepatitis C virus infection. New England Journal of Medicine 334: 1691-1696, 1996.

10. Fox RK, Currie SL, Evans J, Wright TL, Tobler L, Phelps B, Busch MP, Page-Shafer KA. Hepatitis $\mathrm{C}$ virus infection among prisoners in the California state correctional system. Clinical Infectious Diseases 41: 177-186, 2005.

11. Gore SM, Bird AG, Hutchinson SJ. Injector-inmates and anal sex with another man in prison. International Journal of STD \& AIDS 9: 781, 1998
12. Guimarães T, Granato CF, Varella D, Ferraz ML, Castelo A, Kallas EG. High prevalence of hepatitis $\mathrm{C}$ infection in a brazilian prison: identification of risk factors for infection. Brazilian Journal of Infectious Diseases 5: 111-118, 2001 .

13. Holsen DS, Harthug S, Myrmel H. Prevalence of antibodies to hepatitis C vírus and associations with intravenous drug abuse and tattooing in a national prison in Norway. European Journal of Clinical Microbiology \& Infectious Diseases 12: 673-676, 1993

14. Kleinbaum DG. Logistic Regression - a Self-Learning Text. Springer-Verlag, New York, 1994.

15. Long J, Allwright S, Barry J, Reynolds SR, Thornton L, Bradley F, Parry JV. Prevalence of antibodies to hepatitis B, hepatitis C, and HIV and risk factors in entrants to Irish prisons: a national cross sectional survey. British Medical Journal 323: 1209-1213, 2001.

16. Macalino GE, Vlahov D, Sanford-Colby S, Patel S, Sabin K, Salas C, Rich JD. Prevalence and incidence of HIV, hepatitis B virus, and hepatitis $\mathrm{C}$ virus infection among males in Rhode Island Prisons. American Journal of Public Health 94: 1218-1223, 2004.

17. Massad E. HIV/AIDS no sistema prisional brasileiro. In: A epidemia de AIDS no Brasil - Situações e Tendências. Ministério da Saúde,p.87-104, 1997.

18. Massad E, Rozman M, Azevedo RS, Silveira AS, Takey K, Yamamoto YI, Strazza L, Ferreira MM, Burattini MN. Seroprevalence of HIV, HCV and syphilis in Brazilian prisoners: Preponderance of parenteral transmission. European Journal of Epidemiology 15: 439-445, 1999.

19. Mesquita F, Kral A, Reingold A, Bueno R, Trigueiros D, Araujo PJ, Santos Metropolitan Region Collaborative Study Group. Trends of HIV infection among injection drug users in Brazil in the 1990's: the impact of changes in patterns of drug use. Journal of Acquired Immune Deficience Syndrome 28: 298-302, 2001.

20. Oliveira ML, Bastos FI, Telles PR, Yoshida CF, Schatzmayr HG, Paetzold U, Pauli G Schreier E. Prevalence and risk factors for HBV, HCV and HDV infections among injecting drug users from Rio de Janeiro, Brazil. Brazilian Journal of Medical and Biological Research 32: 1107-1114, 1999.

21. Pallás JR, Fariñas-Álvarez C, Prieto D, Llorca J, Delgado-Rodriguez M. Risk factors for monoinfections and coinfections with HIV, hepatitis $B$ and hepatitis $C$ viruses in northern Spanish prisoners. Epidemiology and Infection 123: 95-102, 1999.

22. Poulin C, Alary M, Lambert G, Godin G, Landry S, Gagnon H, Demers E, Morarescu E, Rochefort J. Claessens C. Prevalence of HIV and hepatitis C virus infections among inmates of Quebec provincial prisons. Canadian Medical Association Journal 177: 252-256, 2007

23. Secretaria de Vigilância em Saúde. Sistema de informação de agravos de notificação - SINAN. Ministério da Saúde, Brasil 2007. Disponível em http:// dtr2004.saude.gov.br/sinanweb/. Acessado em 11/11/2007.

24. Tsang THF, Horowitz E, Vugia DJ. Transmission of hepatitis C through tattooing in a United States Prison. American Journal of Gastroenterology 96: 1304-1305, 2001.

25. Vlahov D, Nelson KE, Quinn TC, Kendig N. Prevalence and incidence of hepatitis $\mathrm{C}$ virus infection among male prison inmates in Maryland. European Journal of Epidemiology 9: 566-569, 1993

26. Weild AR, Gill ON, Bennett D, Livingstone SJM, Parry JV, Curran L. Prevalence of HIV, hepatitis B, and hepatitis C antibodies in prisoners in England and Wales: a national survey. Communicable disease and public health 3: 121-126, 2000.

27. Weinbaum CM, Sabin KM, Santibanez SS. Hepatitis B, hepatitis C, and HIV in correctional populations: a review of epidemiology and prevention. AIDS 19 (suppl 3): S41-S46, 2005. 